\title{
Article \\ Optimization of Synthesis Conditions of Ni/SBA-15 Catalysts: Confined Nanoparticles and Improved Stability in Dry Reforming of Methane
}

\author{
Marie-Nour Kaydouh ${ }^{1,2}$ (D) , Nissrine El Hassan ${ }^{1, *(\mathbb{D})}$, Anne Davidson ${ }^{2}$ (D) and Pascale Massiani ${ }^{2, *(\mathbb{D})}$ \\ 1 Department of Chemical Engineering, Faculty of Engineering, University of Balamand, \\ Amioun P.O. Box 33, Lebanon; marienour.kaydouh@gmail.com \\ 2 Laboratoire de Réactivité de Surface, Sorbonne Universités, UPMC Université Paris 06, UMR CNRS 7197, \\ 4 Place Jussieu, 75005 Paris, France; anne.davidson@sorbonne-universite.fr \\ * Correspondence: nissrine.hassan@balamand.edu.lb (N.E.H.); pascale.massiani@upmc.fr (P.M.)
}

Citation: Kaydouh, M.-N.; El Hassan,

N.; Davidson, A.; Massiani, P. Optimization of Synthesis Conditions of Ni/SBA-15 Catalysts: Confined Nanoparticles and Improved Stability in Dry Reforming of Methane. Catalysts 2021, 11, 44. https:// doi.org/10.3390/catal11010044

Received: 23 November 2020 Accepted: 27 December 2020 Published: 31 December 2020

Publisher's Note: MDPI stays neutral with regard to jurisdictional clai$\mathrm{ms}$ in published maps and institutional affiliations.

Copyright: (C) 2020 by the authors. Licensee MDPI, Basel, Switzerland. This article is an open access article distributed under the terms and conditions of the Creative Commons Attribution (CC BY) license (https:// creativecommons.org/licenses/by/ $4.0 /)$.

\begin{abstract}
Despite its economic and environmental advantages, the dry reforming of methane using supported Ni-based catalysts remains challenging due to problems of metal particle sintering and carbon deposition, which lead to loss in catalytic activity. In this study, different silica supports, containing $5 \mathrm{wt} \%$ nickel, were prepared and characterized by $\mathrm{N}_{2}$ sorption, XRD, TPR, and TEM/SEM, in addition to Raman and TGA/MS for the spent catalysts. Different synthesis conditions were thus varied, like nickel deposition method, nature of nickel precursor salt, conditions for thermal activation, and nature of support. The results showed that enhanced metal dispersion, good confinement, and efficient stabilization of the active phase inside the pores can be achieved by using a well-structured mesoporous support. Moreover, it was demonstrated that carbon resistance can be improved when small nickel particles are well confined inside the pores. The strategies that affect the final dispersion of nickel particles, their consequent confinement inside (or deposition outside) the mesopores and the resulting catalytic activity and stability include mainly the application of hydrothermal treatment to the support, the variation of the nature of nickel precursor salt, and the conditions for thermal activation. General guidelines for the preparation of suitable Ni-based catalysts highly active and stable for dry reforming of methane (DRM) are thus presented in this work.
\end{abstract}

Keywords: methane dry reforming; nickel; mesoporous support; internal/external particles; synthesis parameters; precursor salt

\section{Introduction}

Dry reforming of methane (DRM) is the reaction of carbon dioxide with methane to produce syngas, a mixture of hydrogen and carbon monoxide. The major interest of this route resides in the value of $\mathrm{H}_{2}$ : $\mathrm{CO}$ ratio close to one, which is adequate for Fischer-Tropsch synthesis. In front of the alarming global warming effect, mainly due to greenhouse gas emissions on the one hand and the abundance of biomass and its increasing potential on the other hand, dry reforming of methane emerges as a promising reaction on the environmental, economic, and energetic levels. Noble metals, like $\mathrm{Pt}, \mathrm{Ru}$, and $\mathrm{Rh}$ for example, are highly stable in such applications [1-3]; they are resistant to carbon deposition and maintain high conversions, however they are not economical. Therefore, transition metals like $\mathrm{Ni}$ and Co became potential alternatives due to their availability and costeffectiveness [4,5]. Nevertheless, the loss of activity (i.e., deactivation) of nickel-based catalysts is a major drawback, primarily assigned to metal particles sintering, especially at high temperatures, and to heavy carbon deposition during reaction [6].

Recent studies focus on the importance of metal confinement for improved resistance towards metal sintering and carbon deposition, and thus enhanced stability. Among the different structured catalysts, spinels, perovskites, $\mathrm{ZrO}_{2}$, and ordered mesoporous 
silica $[7,8]$ are used. Indeed, researchers observed $\mathrm{Ni}$ particle sintering on nonporous $\mathrm{NiCaZr}$ catalyst; but when a porous support was used, the growth of Ni was limited due to the confinement effect [9]. Mesoporous Santa Barbara Amorphous silica (SBA-15) supports, in particular, are well-known mesoporous silica materials, characterized by a uniform hexagonal pore arrangement giving high surface area, large porous volume, and uniform pore size distribution [10]. The large surface area allows an important dispersion of metal particles while improving the accessibility and the exposure of the active phase to reactants. It was shown in recent studies that the stabilization inside the pores blocks the particles from migrating towards the surface [11,12]. It is assumed that inside the pores these particles are well confined, they cannot grow more than the limited pore size of the silica support and this prevents their sintering. Inside the pores, there is a spatial restriction on carbon deposition and growth on these nanoparticles and the catalysts are thus more stable [7]. In the same direction, this prevention of particles sintering inside the pores is quasi-absent outside the pores. On the external surface, the particles can easily aggregate under the effect of high temperature, leading to loss in the metal active area accessible to reactants. However, there was no clear demonstration that particles inside well-defined mesopores are more active than those distributed on the external surface of the mesoporous support. So far, there has been no study that evidently compared the effect of the different particle locations on a mesoporous support for dry reforming of methane. One study [13] investigated this effect on carbon nanotubes and found higher conversions and improved stabilities when $\mathrm{Ni}$ particles were loaded inside the channels. Similar studies were conducted for Fischer-Tropsch synthesis that also used carbon nanotubes as supports. The confinement of Fe [14,15] and Co [16] inside the nanotubes resulted in an enhanced catalytic performance, even for particles of comparable size inside and outside the nanotubes. This was attributed to different metal-support interactions depending on the particle position, to increased contact time of reactants with active sites and to prevention of particles agglomeration inside the nanotubes.

Furthermore, the deposition and confinement of nickel particles can be greatly influenced by the nature of the metal salt precursor employed. Particularly, nickel chloride is reported to generate large external nickel particles [17-19], while nitrate and acetate nickel precursors favor internal dispersion of small nanoparticles $[20,21]$. However, a prompt comparison between these various precursors for nickel supported on silica-based materials and tested in the DRM reaction has not yet been performed under the same conditions. Consequently, different parameters can affect the properties of the resulting catalyst. Indeed, the synthesis and impregnation procedures have a major role in the dispersion, metal particle size, catalytic activity, and carbon resistance [3]. Thus, the aim of this study is to vary the catalysts preparation methods and to evaluate their effect on the achievement of good Ni confinement inside a well-developed porosity. Such well-confined nanoparticles should have superior catalytic activity and stability and enhanced resistance towards deactivation in comparison with nonconfined particles, deposited on the external surface. Therefore, this study evaluates in details the changes in the pore structure of SBA-15 due to hydrothermal treatment and its direct influence on the catalytic activity during DRM, which has not yet been reported. In addition, different nickel precursors and different supports are used to prepare catalysts with external and/or internal Ni particles, having different particle sizes and different metal-support interactions, and next evaluate their activity and stability in dry reforming of methane at $650{ }^{\circ} \mathrm{C}$.

\section{Results}

\subsection{Characterization of Calcined Samples}

The $\mathrm{N}_{2}$ sorption isotherms of the calcined samples are shown in Figure 1. According to the updated International Union of Pure and Applied Chemistry (IUPAC) manual on the physisorption of gases [22], all SBA-15-supported samples presented a type IVa isotherm. First, SBA-15-supported catalyst (Figure 1a,a'), not subjected to any hydrothermal treatment, showed a hysteresis loop of type H2(a) characteristic of pore-blocking/percolation 
in a narrow range of pore necks or due to cavitation-induced evaporation [22]. The smooth adsorption step and sharper desorption step in this case indicate the presence of nonuniform cylindrical mesopores, with an average desorption pore size of about $3.6 \mathrm{~nm}$. Second, the $\mathrm{SiO}_{2}$ support and $\mathrm{Ni} / \mathrm{SiO}_{2}(\mathrm{~N})$ catalyst (Figure $1 \mathrm{~b}, \mathrm{~b}^{\prime}$ ) displayed typical isotherms for nonporous or macroporous solid. Third, the SBA-15 $5_{\mathrm{HT}}$-supported catalysts (Figure $1 \mathrm{c}, \mathrm{c}^{\prime}, \mathrm{c}^{\prime \prime}, \mathrm{c}^{\prime \prime \prime}$ ) presented a type $\mathrm{H} 1$ loop that is due to the presence of narrow-range uniform mesopores [22]. The parallel adsorption and desorption steps and the absence of a considerable tail between relative pressures of 0.5 and 0.65 validate the absence of partially blocked mesopores and indicate that all $\mathrm{Ni}$ particles were readily available and accessible for the reactants during the DRM testing $[23,24]$. While the shape of the isotherm was almost identical regardless of the nickel precursor used, the surface area and pore volume of Ni/SBA-15 $5_{\mathrm{HT}}(\mathrm{N})$ were relatively higher than those of $\mathrm{Ni} / \mathrm{SBA}-15_{\mathrm{HT}}(\mathrm{Cl})$ and Ni/SBA$15_{\mathrm{HT}}(\mathrm{A})$. Fourth, the SBA- $15_{\mathrm{com}}$ and Ni/SBA-15 $5_{\mathrm{com}}(\mathrm{N})$ samples (Figure $1 \mathrm{~d}, \mathrm{~d}^{\prime}$ ) presented a type $\mathrm{H} 1$ hysteresis loop, indicative of narrow distribution of uniform mesopores or of ink-bottle pores [22].

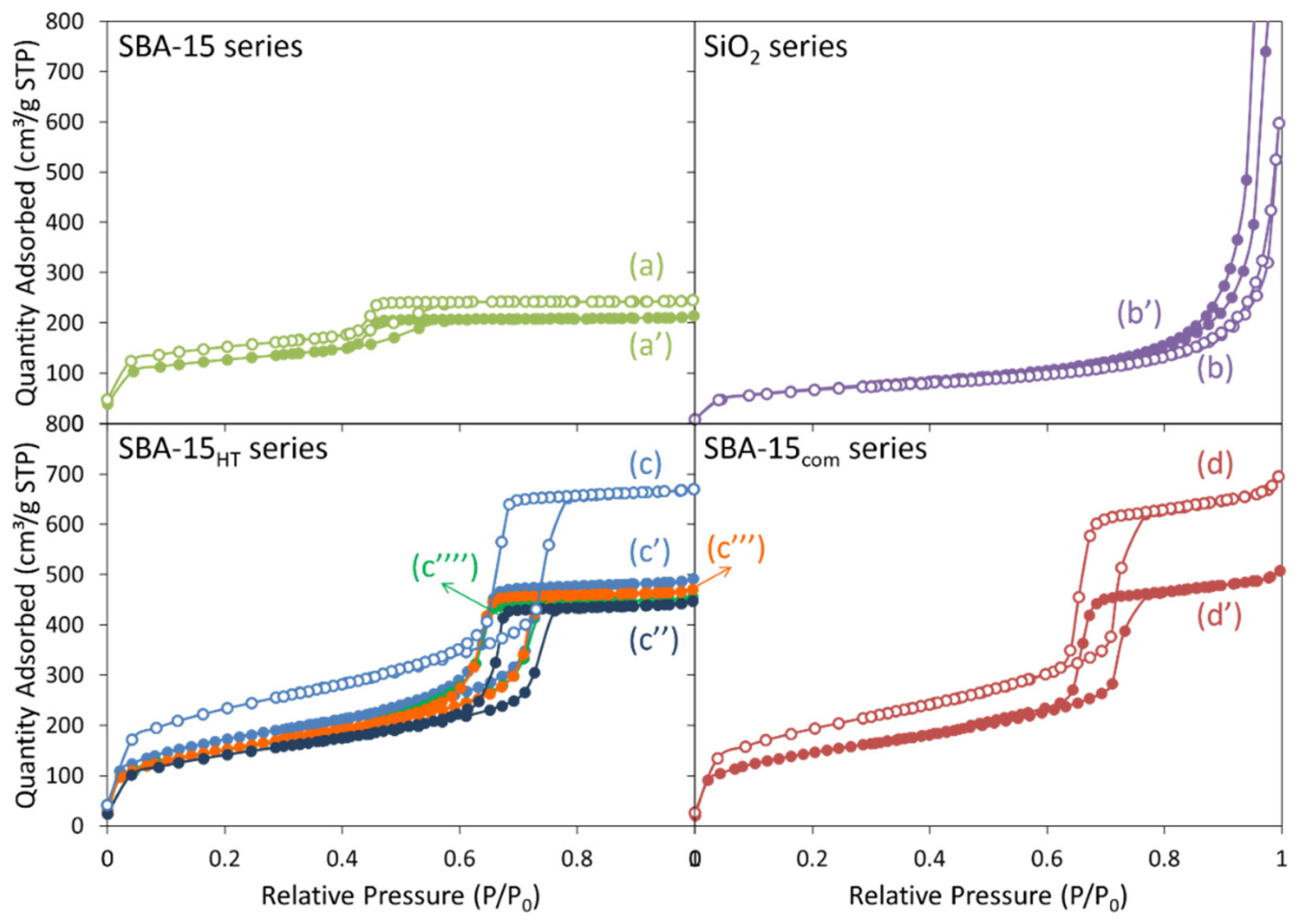

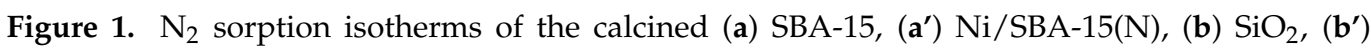
$\mathrm{Ni} / \mathrm{SiO}_{2}(\mathrm{~N}),(\mathrm{c}) \mathrm{SBA}-15_{\mathrm{HT}},\left(\mathrm{c}^{\prime}\right) \mathrm{Ni} / \mathrm{SBA}-15_{\mathrm{HT}}(\mathrm{N}),\left(\mathrm{c}^{\prime \prime}\right) \mathrm{Ni} / \mathrm{SBA}-15_{\mathrm{HT}}(\mathrm{R}),\left(\mathrm{c}^{\prime \prime \prime}\right) \mathrm{Ni} / \mathrm{SBA}-15_{\mathrm{HT}}(\mathrm{A}),\left(\mathrm{c}^{\prime \prime \prime \prime}\right)$ $\mathrm{Ni} / \mathrm{SBA}-15_{\mathrm{HT}}(\mathrm{Cl}),(\mathbf{d}) \mathrm{SBA}-15_{\mathrm{com}}$, and $\left(\mathbf{d}^{\prime}\right) \mathrm{Ni} / \mathrm{SBA}-15_{\mathrm{com}}(\mathrm{N})$.

The X-ray diffractograms of the calcined samples (Figure 2) reveal a broad signal at around $22^{\circ}$ corresponding to $\mathrm{X}$-rays diffusion by amorphous silica walls and narrower diffractions peaks at $37,43,62,76$, and $81^{\circ}$ characteristic of nickel oxide (JCPDS 73-1523) with a face-centered cubic lattice (Fm-3m), as obtained in a previous study [12], and their average particle sizes (Table 1) were estimated from the full width at half maximum (FWHM) using the Scherrer equation, detailed in Section 4.2. These peaks are almost absent on $\mathrm{Ni} / \mathrm{SBA}-15_{\mathrm{HT}}(\mathrm{A})$ (Figure $2 \mathrm{a}$ ), indicative of the formation of very small NiO nanoparticles. Similarly, small NiO nanoparticles were found on Ni/SBA-15 $5_{\text {com }}(\mathrm{N})$ (Figure $2 \mathrm{~b}$ ), whereas the largest $\mathrm{NiO}$ nanoparticles were formed on $\mathrm{Ni} / \mathrm{SBA}-15_{\mathrm{HT}}(\mathrm{Cl}$ ) (Figure $2 \mathrm{~d}$ ) and $\mathrm{Ni} / \mathrm{SiO}_{2}(\mathrm{~N})$ (Figure 2f). On the latter, the absence of mesoporous structure influenced the formation of large $\mathrm{NiO}$ particles and poor dispersion. The use of chloride nickel precursor 
contributed in the formation of large particles $(\sim 19 \mathrm{~nm})$, predominantly on the outer surface of the support.

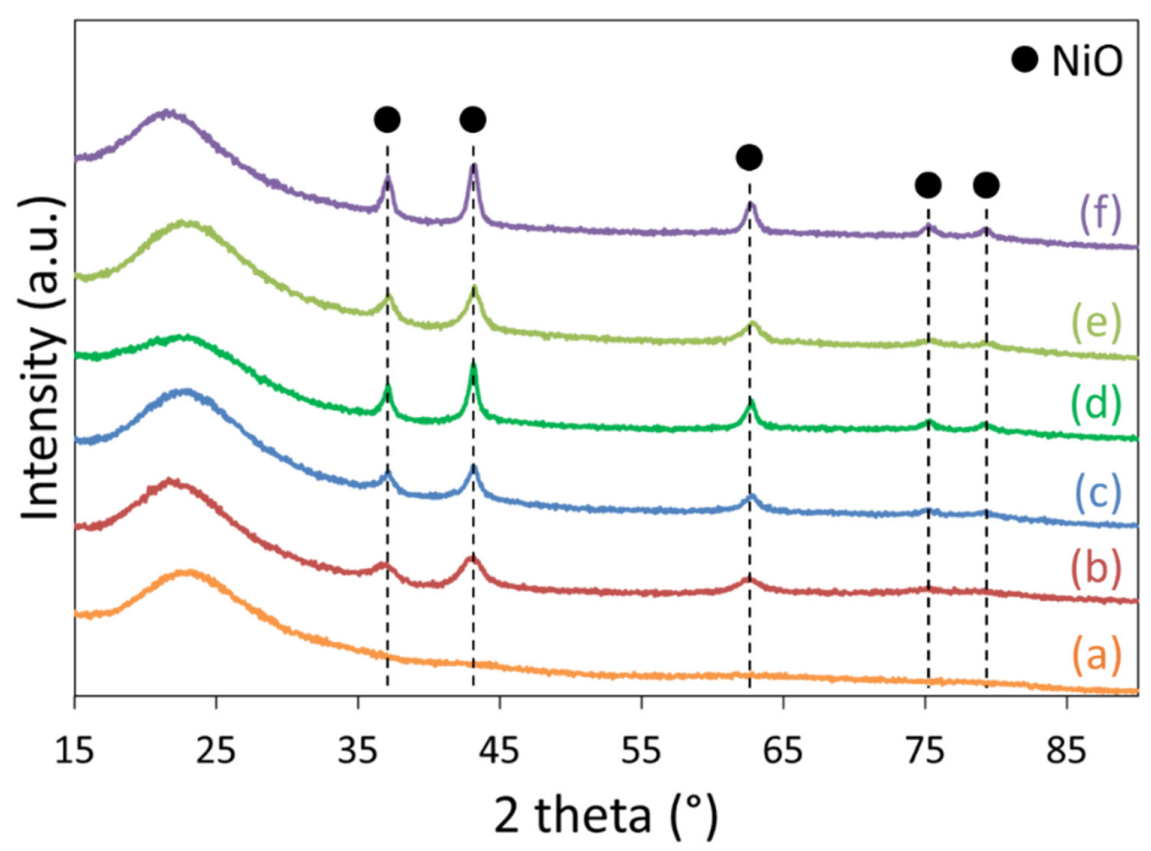

Figure 2. X-ray diffractograms of the calcined (a) Ni/SBA- $15_{\mathrm{HT}}(\mathrm{A}),(\mathbf{b}) \mathrm{Ni} / \mathrm{SBA}-15_{\mathrm{com}}(\mathrm{N}),(\mathbf{c}) \mathrm{Ni} / \mathrm{SBA}$ $15_{\mathrm{HT}}(\mathrm{N}),(\mathbf{d}) \mathrm{Ni} / \mathrm{SBA}-15_{\mathrm{HT}}(\mathrm{Cl}),(\mathbf{e}) \mathrm{Ni} / \mathrm{SBA}-15(\mathrm{~N})$, and (f) $\mathrm{Ni} / \mathrm{SiO}_{2}(\mathrm{~N})$.

The heterogeneous dispersion, depending on the preparation and type of support, was further confirmed on the TEM images (Figure 3). The Ni/SBA-15(N) sample was composed of connected extended grains having a width of 700-800 nm (Figure 3a). Some external $\mathrm{NiO}$ particles can be observed on the outer surface of the SBA-15 support. More importantly, very small nanoparticles are aligned within the channels of this support, confirming their internal deposition inside the pores. The SBA- $15_{\mathrm{HT}}$-supported catalysts (Figure 3b-d) mainly have a two-dimensional (2D) hexagonal structure with elongated grains that are 700-800 $\mathrm{nm}$ long and 500-600 $\mathrm{nm}$ wide. The small particles aligned with the pores of the supports suggest a relatively good $\mathrm{NiO}$ dispersion on these samples (mean sizes of the nanoparticles of about $6 \mathrm{~nm}$ ); however, when nickel chloride was used as the precursor salt (Figure 3c), more particles were rather deposited on the external surface of the support. Furthermore, small particles well dispersed in the channels of the SBA-15 support are observed on the $\mathrm{Ni} / \mathrm{SBA}-15_{\mathrm{HT}}(\mathrm{R})$ sample, directly reduced without calcination (Figure 3d). Similarly, the Ni/SBA- $15_{\mathrm{com}}(\mathrm{N})$ sample (Figure 3e) appears to be formed of elongated grains that are 700-800 $\mathrm{nm}$ long and 500-600 nm wide. On this sample, the alignment of the small $\mathrm{NiO}$ nanoparticles along the channels of the support demonstrates their internal deposition. Finally, the TEM image of the $\mathrm{Ni} / \mathrm{SiO}_{2}(\mathrm{~N})$ sample (Figure 3f) validates its amorphous aspect, which lacks a well-defined structure, and proves that large $\mathrm{NiO}$ nanoparticles were formed, as also estimated using XRD (Table 1). 
Table 1. Characteristics of the calcined, reduced, and spent catalysts.

\begin{tabular}{|c|c|c|c|c|c|c|c|c|c|c|}
\hline- & - & & & & & & & Reduced & $\mathrm{Sp}$ & \\
\hline Sample & $\begin{array}{l}\text { Nickel } \\
\text { Precursor } \\
\text { Salt }\end{array}$ & $\begin{array}{c}\text { BET SA * } \\
\left(\mathrm{m}^{2} / \mathrm{g}\right)\end{array}$ & $\begin{array}{c}\text { Meso-Porous } \\
\text { Area } \\
\left(\mathrm{m}^{2} / \mathrm{g}\right)\end{array}$ & $\begin{array}{l}\text { Pore Volume } \\
\quad\left(\mathrm{cm}^{3} / \mathrm{g}\right)\end{array}$ & $\begin{array}{c}\text { Average } \\
\text { Adsorption } \\
\text { Pore Width } \\
\quad(\mathrm{nm})\end{array}$ & $\begin{array}{c}\text { Average } \\
\text { Desorption } \\
\text { Pore Width } \\
\quad(\mathrm{nm})\end{array}$ & $\begin{array}{l}\text { NiO Size } \\
\text { (nm) }\end{array}$ & $\begin{array}{c}\mathrm{Ni}^{0} \text { Size Reduced } \\
(\mathrm{nm})\end{array}$ & $\begin{array}{c}\mathrm{Ni}^{0} \text { Size Spent } \\
(\mathrm{nm})\end{array}$ & $\begin{array}{l}\mathrm{I}_{\mathrm{D}} / \mathrm{I}_{\mathrm{G}}{ }^{* *} \\
\text { (Raman) }\end{array}$ \\
\hline SBA-15 $5_{\mathrm{HT}}$ & - & 832 & 678 & 0.97 & 6.4 & 6.0 & - & - & - & - \\
\hline $\mathrm{Ni} / \mathrm{SBA}-15_{\mathrm{HT}}(\mathrm{N})$ & Nitrate & 620 & 551 & 0.71 & 5.7 & 5.5 & 6.0 & 6.4 & 6.3 & 1.6 \\
\hline $\mathrm{Ni} / \mathrm{SBA}-15_{\mathrm{HT}}(\mathrm{Cl})$ & Chloride & 545 & 491 & 0.68 & 5.7 & 5.3 & 19.0 & 8.2 & 10.3 & - \\
\hline $\mathrm{Ni} / \mathrm{SBA}-15_{\mathrm{HT}}(\mathrm{A})$ & Acetate & 549 & 495 & 0.70 & 5.8 & 5.5 & n.d. & $<3$ & 3.7 & - \\
\hline $\mathrm{Ni} / \mathrm{SBA}-15_{\mathrm{HT}}(\mathrm{R})$ & Nitrate & 509 & 445 & 0.66 & 6.4 & 6.0 & - & 4.4 & 4.7 & 0.95 \\
\hline SBA-15 & - & 522 & 290 & 0.35 & 3.4 & 3.5 & - & - & - & - \\
\hline $\mathrm{Ni} / \mathrm{SBA}-15(\mathrm{~N})$ & Nitrate & 436 & 262 & 0.30 & 3.5 & 3.6 & 6.2 & n.d. & n.d. & 2.0 \\
\hline SBA-15 $5_{\text {com }}$ & - & 701 & 640 & 1.04 & 6.7 & 6.6 & - & - & - & - \\
\hline $\mathrm{Ni} / \mathrm{SBA}-15_{\mathrm{com}}(\mathrm{N})$ & Nitrate & 529 & 480 & 0.75 & 6.5 & 6.3 & 3.9 & 3.8 & 4.3 & - \\
\hline $\mathrm{SiO}_{2}$ & - & 239 & - & - & - & - & - & - & - & - \\
\hline $\mathrm{Ni} / \mathrm{SiO}_{2}(\mathrm{~N})$ & Nitrate & 247 & - & - & - & - & 9.0 & n.d. & 7.6 & - \\
\hline
\end{tabular}

n.d. not determined. * BET SA: Brunauer-Emmett-Teller Surface Area. ${ }^{* *} \mathrm{I}_{\mathrm{D}} / \mathrm{I}_{\mathrm{G}}$ : ratio of the intensity of the D-band with respect to that of the G-band (Raman). 

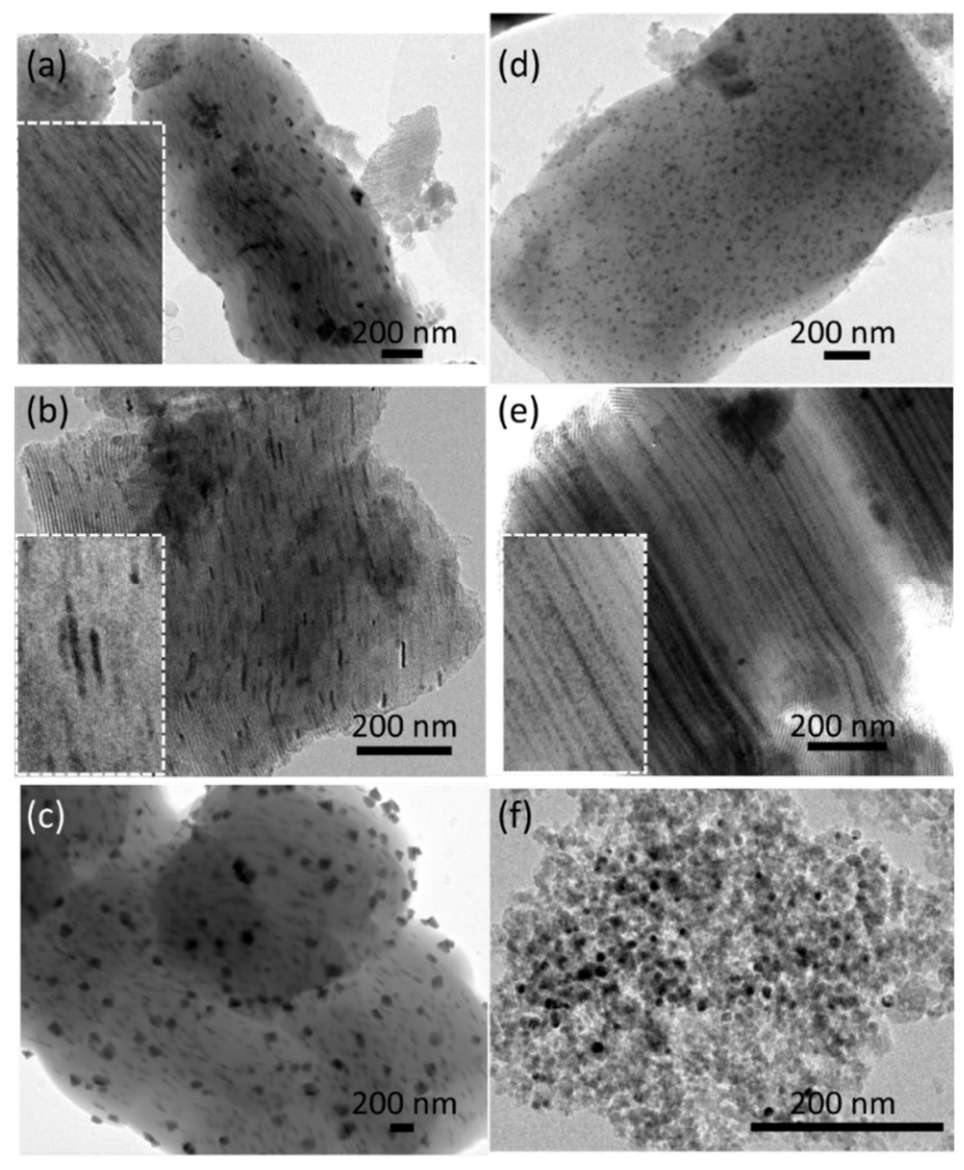

Figure 3. TEM images of the calcined (a) Ni/SBA-15(N), (b) Ni/SBA- $15_{\mathrm{HT}}(\mathrm{N}),(\mathbf{c}) \mathrm{Ni} / \mathrm{SBA}-15_{\mathrm{HT}}(\mathrm{Cl})$, (d) $\mathrm{Ni} / \mathrm{SBA}-15_{\mathrm{HT}}(\mathrm{R}),(\mathbf{e}) \mathrm{Ni} / \mathrm{SBA}-15_{\mathrm{com}}(\mathrm{N})$, and (f) $\mathrm{Ni} / \mathrm{SiO}_{2}(\mathrm{~N})$ samples.

\subsection{Catalytic Test Results}

After reduction at $650{ }^{\circ} \mathrm{C}$ for $2 \mathrm{~h}$ under a flow of $5 \% \mathrm{H}_{2} / \mathrm{Ar}$, the reactor temperature was cooled to about $200{ }^{\circ} \mathrm{C}$ and then increased again under the reactants flow up to $750{ }^{\circ} \mathrm{C}$. The evolution of reactant conversions as a function of temperature are reported in Table 2. The majority of the catalysts showed comparable trends at a gas hourly space velocity (GHSV) of $36 \mathrm{~L} \cdot \mathrm{g}^{-1} \cdot \mathrm{h}^{-1}$, and approximately $50 \% \mathrm{CH}_{4}$ and $\mathrm{CO}_{2}$ conversions were achieved at around $550-600{ }^{\circ} \mathrm{C}$, and more than $95 \%$ conversions at $750{ }^{\circ} \mathrm{C}$. These conversions were very close to the expected thermodynamic values calculated using the HSC chemistry software, when considering the DRM reaction under the used experimental conditions and the possible water formation, without including the possible solid carbon deposition. This choice was selected on the basis of the relatively low and limited amount of carbon deposited during the reaction, as will be shown and discussed in the following sections. As expected, the activity of $\mathrm{Ni} / \mathrm{SBA}-15_{\mathrm{HT}}(\mathrm{Cl})$ was remarkably lower than that of the remaining samples, and in this case, a maximum conversion of only $65 \%$ was attained at $750{ }^{\circ} \mathrm{C}$.

Even though all catalysts revealed a similar behavior during the increase of temperature, the catalytic stability differed from one support to another, probably due to some deactivation associated with $\mathrm{Ni}$ particles sintering and/or carbon deposition. Indeed, Figure 4 shows reactants conversions and $\mathrm{H}_{2}: \mathrm{CO}$ molar ratios as a function of time at $650{ }^{\circ} \mathrm{C}$ under reactants flow. Among the different SBA- $15_{\mathrm{HT}}$-supported catalysts, the $\mathrm{Ni} / \mathrm{SBA}-15_{\mathrm{HT}}(\mathrm{Cl})$ was less active and less stable than both Ni/SBA-15 $5_{\mathrm{HT}}(\mathrm{A})$ and $\mathrm{Ni} / \mathrm{SBA}-$ $15_{\mathrm{HT}}(\mathrm{N})$ and the catalytic activity of $\mathrm{Ni} / \mathrm{SBA}-15_{\mathrm{HT}}(\mathrm{R})$ directly reduced without calcination was comparable to that of the pre-calcined $\mathrm{Ni} / \mathrm{SBA}-15_{\mathrm{HT}}(\mathrm{N})$. Both $\mathrm{Ni} / \mathrm{SBA}-15_{\mathrm{HT}}(\mathrm{A})$ and $\mathrm{Ni} / \mathrm{SBA}-15_{\mathrm{HT}}(\mathrm{N})$ showed high catalytic activity, and the conversions of $\mathrm{CO}_{2}$ and $\mathrm{CH}_{4}$ were about $80-85 \%$ and $75 \%$, respectively. The catalytic activity of $\mathrm{Ni} / \mathrm{SBA}-15_{\mathrm{HT}}(\mathrm{Cl})$ catalyst 
was much lower, the initial conversions of $\mathrm{CO}_{2}$ and $\mathrm{CH}_{4}$ being $50 \%$ and $40 \%$, respectively. The origin of these differences will be analyzed in more detail in Section 3.

Table 2. Variation of $\mathrm{CH}_{4}$ and $\mathrm{CO}_{2}$ conversions and $\mathrm{H}_{2}: \mathrm{CO}$ molar ratio with temperature during the heat-up phase.

\begin{tabular}{|c|c|c|c|c|c|c|c|c|c|c|c|c|c|c|c|c|c|c|}
\hline \multirow{2}{*}{$\frac{-}{\text { Temperature }\left({ }^{\circ} \mathrm{C}\right)}$} & \multicolumn{6}{|c|}{$\mathrm{CH}_{4}(\%)$} & \multicolumn{6}{|c|}{$\mathrm{CO}_{2}(\%)$} & \multicolumn{6}{|c|}{$\mathrm{H}_{2}$ :CO Ratio } \\
\hline & 500 & 550 & 600 & 650 & 700 & 750 & 500 & 550 & 600 & 650 & 700 & 750 & 500 & 550 & 600 & 650 & 700 & 750 \\
\hline $\begin{array}{l}\text { Thermodynamic } \\
\text { Equilibrium }\end{array}$ & 37 & 56 & 74 & 86 & 93 & 96 & 46 & 64 & 81 & 90 & 96 & 98 & 0.79 & 0.86 & 0.91 & 0.95 & 0.97 & 0.98 \\
\hline $\mathrm{Ni} / \mathrm{SBA}-15_{\mathrm{HT}}(\mathrm{N})$ & 24 & 43 & 64 & 77 & 88 & 92 & 30 & 49 & 68 & 83 & 92 & 95 & 0.8 & 0.99 & 1.08 & 1.03 & 1.08 & 1.08 \\
\hline $\mathrm{Ni} / \mathrm{SBA}-15_{\mathrm{HT}}(\mathrm{Cl})$ & 0 & 1 & 5 & 8 & 18 & 65 & 0 & 3 & 7 & 15 & 38 & 73 & 0 & 0.14 & 0.2 & 0.37 & 0.53 & 0.97 \\
\hline $\mathrm{Ni} / \mathrm{SBA}-15_{\mathrm{HT}}(\mathrm{A})$ & 10 & 26 & 50 & 74 & 88 & 95 & 14 & 32 & 56 & 77 & 88 & 94 & 0.62 & 0.82 & 0.94 & 1.4 & 1.11 & 1.13 \\
\hline $\mathrm{Ni} / \mathrm{SBA}-15_{\mathrm{HT}}(\mathrm{R})$ & 20 & 37 & 58 & 75 & 88 & 95 & 26 & 44 & 64 & 80 & 88 & 94 & 0.78 & 0.88 & 0.98 & 1.05 & 1.11 & 1.13 \\
\hline $\mathrm{Ni} / \mathrm{SBA}-15(\mathrm{~N})$ & 19 & 37 & 58 & 72 & 84 & 92 & 25 & 42 & 62 & 79 & 90 & 95 & 0.88 & 1.07 & 1.20 & 1.15 & 1.20 & 1.25 \\
\hline $\mathrm{Ni} / \mathrm{SBA}-15_{\text {com }}(\mathrm{N})$ & 22 & 40 & 60 & 76 & 88 & 95 & 28 & 45 & 66 & 80 & 90 & 94 & 0.78 & 0.89 & 0.99 & 1.05 & 1.11 & 1.14 \\
\hline $\mathrm{Ni} / \mathrm{SiO}_{2}(\mathrm{~N})$ & 18 & 38 & 62 & 72 & 84 & 93 & 24 & 42 & 60 & 76 & 87 & 93 & 0.77 & 0.98 & 1.16 & 1.04 & 1.08 & 1.12 \\
\hline
\end{tabular}

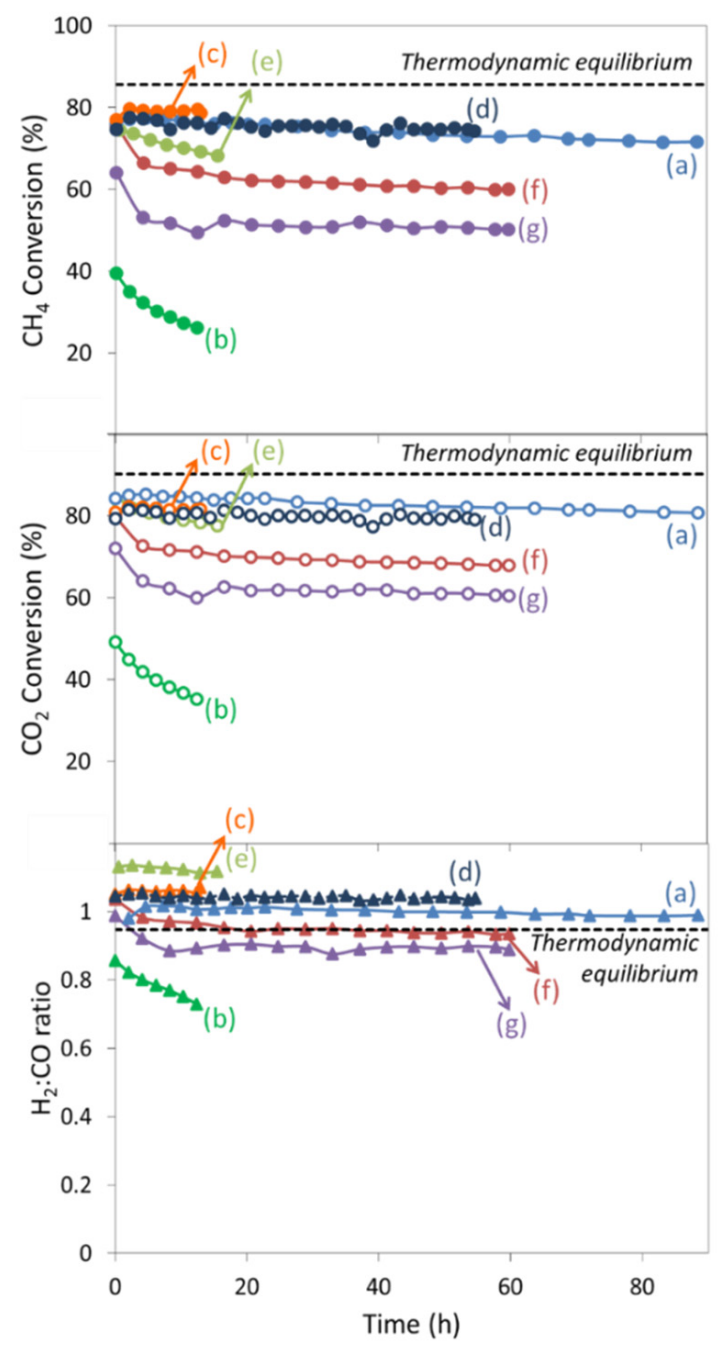

Figure 4. Variation of $\mathrm{CH}_{4}$ (filled circles) and $\mathrm{CO}_{2}$ (empty circles) conversions and $\mathrm{H}_{2}: \mathrm{CO}$ molar ratio (triangles) with time at $650{ }^{\circ} \mathrm{C}\left(36 \mathrm{~L} \cdot \mathrm{g}^{-1} \cdot \mathrm{h}^{-1}\right.$ and $\left.\mathrm{CH}_{4}: \mathrm{CO}_{2}: \mathrm{Ar}=5: 5: 90\right)$ for $(\mathbf{a}) \mathrm{Ni} / \mathrm{SBA}-15_{\mathrm{HT}}(\mathrm{N})$, (b) Ni/SBA-15 $5_{\mathrm{HT}}(\mathrm{Cl})$, (c) Ni/SBA-15 $5_{\mathrm{HT}}(\mathrm{A})$, (d) Ni/SBA-15 ${ }_{\mathrm{HT}}(\mathrm{R}),(\mathbf{e}) \mathrm{Ni} / \mathrm{SBA}-15(\mathrm{~N}),(\mathbf{f}) \mathrm{Ni} / \mathrm{SBA}-$ $15_{\text {com }}(\mathrm{N})$, and $(\mathrm{g}) \mathrm{Ni} / \mathrm{SiO}_{2}(\mathrm{~N})$. 
The conversions and stabilities of the remaining catalysts changed according to the type of support used. First, superior conversions at steady state were attained on mesoporous catalysts, in opposition to nonporous $\mathrm{Ni} / \mathrm{SiO}_{2}(\mathrm{~N})$ on which conversion declined. Second, the conversions over Ni/SBA-15(N) prepared without hydrothermal treatment decreased with time. Third, some loss of activity was observed at the beginning of the stability test on the $\mathrm{Ni} / \mathrm{SiO}_{2}(\mathrm{~N})$ catalyst, and the $\mathrm{CH}_{4}$ and $\mathrm{CO}_{2}$ conversions were afterwards maintained at around 50 and $60 \%$, respectively. Nevertheless, these conversions were still much lower than those on $\mathrm{Ni} / \mathrm{SBA}-15_{\mathrm{HT}}(\mathrm{N})$ catalyst. Indeed, among these samples, only the Ni/SBA- $15_{\mathrm{HT}}(\mathrm{N})$ maintained stable $\mathrm{CH}_{4}$ and $\mathrm{CO}_{2}$ conversion levels, for more than $90 \mathrm{~h}$ on-stream, at the same level as that shown during the heat-up phase. All remaining samples showed lower $\mathrm{CH}_{4}$ and $\mathrm{CO}_{2}$ conversions than those presented during the activity measurements at $650{ }^{\circ} \mathrm{C}$ (Table 2). Further differences between samples were also depicted from the $\mathrm{H}_{2}$ and $\mathrm{CO}$ products selectivity and yield (Table 3), calculated from the stability measurements after 1 and $12 \mathrm{~h}$ on stream. First, the products selectivity for all samples was close to $100 \%$, validating the selectivity of the catalysts towards the main dry reforming reaction rather than side reactions. In general, the selectivity of $\mathrm{H}_{2}$ was slightly higher than that of CO, probably due to the occurrence of the Reverse Water Gas Shift reaction (RWGS), as further revealed in the $\mathrm{H}_{2}: \mathrm{CO}$ ratio slightly higher than unity. The major differences were observed while considering the products yields. In fact, the $\mathrm{H}_{2}$ and $\mathrm{CO}$ yields were the highest and the most stable for the Ni/SBA- $15_{\mathrm{HT}}(\mathrm{N})$ and the lowest for both Ni/SBA$15_{\mathrm{HT}}(\mathrm{Cl})$ and $\mathrm{Ni} / \mathrm{SiO}_{2}(\mathrm{~N})$. The remaining samples showed intermediate values (Table 3). These results indicate the suitability of nickel nitrate as precursor salt, in agreement with previous publications [21], and provide a more complete comparison with other precursors for $\mathrm{Ni} /$ silica-based materials for DRM.

Table 3. Products selectivity and yield during stability measurements after 1 and $12 \mathrm{~h}$ on stream.

\begin{tabular}{|c|c|c|c|c|c|c|c|c|}
\hline \multirow{3}{*}{$\begin{array}{c}- \\
\text { Product } \\
\text { Duration }\end{array}$} & \multicolumn{4}{|c|}{ Selectivity (\%) } & \multicolumn{4}{|c|}{ Yield (\%) } \\
\hline & \multicolumn{2}{|c|}{$\mathrm{H}_{2}$} & \multicolumn{2}{|c|}{$\mathrm{CO}$} & \multicolumn{2}{|c|}{$\mathrm{H}_{2}$} & \multicolumn{2}{|c|}{$\mathrm{CO}$} \\
\hline & $1 \mathrm{~h}$ & $12 \mathrm{~h}$ & $1 \mathrm{~h}$ & $12 \mathrm{~h}$ & $1 \mathrm{~h}$ & $12 \mathrm{~h}$ & $1 \mathrm{~h}$ & $12 \mathrm{~h}$ \\
\hline $\mathrm{Ni} / \mathrm{SBA}-15_{\mathrm{HT}}(\mathrm{N})$ & 100 & 100 & 99 & 100 & 79 & 80 & 79 & 79 \\
\hline $\mathrm{Ni} / \mathrm{SBA}-15_{\mathrm{HT}}(\mathrm{Cl})$ & 80 & 84 & 100 & 100 & 33 & 21 & 41 & 33 \\
\hline $\mathrm{Ni} / \mathrm{SBA}-15_{\mathrm{HT}}(\mathrm{A})$ & 100 & 100 & 88 & 88 & 81 & 81 & 72 & 71 \\
\hline $\mathrm{Ni} / \mathrm{SBA}-15_{\mathrm{HT}}(\mathrm{R})$ & 95 & 95 & 80 & 81 & 73 & 74 & 64 & 65 \\
\hline Ni/SBA-15(N) & 96 & 93 & 80 & 79 & 71 & 65 & 63 & 58 \\
\hline $\mathrm{Ni} / \mathrm{SBA}-15_{\mathrm{com}}(\mathrm{N})$ & 98 & 94 & 87 & 87 & 73 & 61 & 66 & 59 \\
\hline $\mathrm{Ni} / \mathrm{SiO}_{2}(\mathrm{~N})$ & 97 & 93 & 99 & 99 & 56 & 45 & 62 & 57 \\
\hline
\end{tabular}

\section{Discussion}

\subsection{Effect of Porous Structure}

Higher initial conversions and better stabilities were observed on most of the Ni/SBA15 samples (Figure 4), while lower initial conversions and lower products yields (Table 3) were detected on $\mathrm{Ni} / \mathrm{SiO}_{2}(\mathrm{~N})$ catalyst. Thus, the catalysts having a mesoporous structure showed better catalytic activity than the $\mathrm{SiO}_{2}$-supported catalyst. This reveals the importance of mesoporous structure in order to have a good catalytic activity and stability, as also mentioned elsewhere $[9,25,26]$. As reported, the mesoporous structure improves metals dispersion and limits their growth up to the pore dimension, consequently hindering any sintering effect that can result from the high temperature applied [12].

As expected, the Ni/SBA-15(N) catalyst showed lower surface area and pore volume than the Ni/SBA-15 $5_{\mathrm{HT}}(\mathrm{N})$ sample. During the dry reforming test, the Ni/SBA-15 $5_{\mathrm{HT}}(\mathrm{N})$ was more stable than the $\mathrm{Ni} / \mathrm{SBA}-15(\mathrm{~N})$ and maintained an $\mathrm{H}_{2}$ : $\mathrm{CO}$ molar ratio closer to unity in addition to higher products selectivity and yields. The application of the hydrothermal 
treatment on the SBA-15 support ameliorated the textural properties of the support by increasing the Brunauer-Emmett-Teller (BET) surface area, pore volume, and pore sizes. This contributed in the enhancement of mesoporous structure, as demonstrated in the small-angle XRD results (Figure 5). The three diffraction peaks, indexed as (100), (110), and (200), characteristic of the highly ordered p6mm hexagonal mesoporous structure [27], are much more resolved on $\mathrm{Ni} / \mathrm{SBA}-15_{\mathrm{HT}}(\mathrm{N})$ than on Ni/SBA-15(N). This is also validated in the TEM image shown for the Ni/SBA-15 $5_{\mathrm{HT}}(\mathrm{N})$ sample (inset Figure 5). The (100) diffraction peak appears to be shifted towards higher angles in the case of Ni/SBA$15(\mathrm{~N})$ sample, resulting in a lower $\mathrm{d}_{100}$ spacing of about $7.8 \mathrm{~nm}$, compared to $9.3 \mathrm{~nm}$ for $\mathrm{Ni} / \mathrm{SBA}-15_{\mathrm{HT}}(\mathrm{N})$. Furthermore, the intensity of the (100) diffraction peak is much lower on $\mathrm{Ni} / \mathrm{SBA}-15(\mathrm{~N})$ than on $\mathrm{Ni} / \mathrm{SBA}-15_{\mathrm{HT}}(\mathrm{N})$, suggesting that enhanced structure can be obtained using the hydrothermal treatment. Indeed, previous reports show that more condensed silica walls and bigger pore diameters are formed upon the application of hydrothermal treatment [12,28-30]. Hence, the hydrothermal treatment is essential in providing improved thermal stability of the support and better nickel nanoparticles confinement inside the pores, which result in better catalytic activity during the reforming reaction.

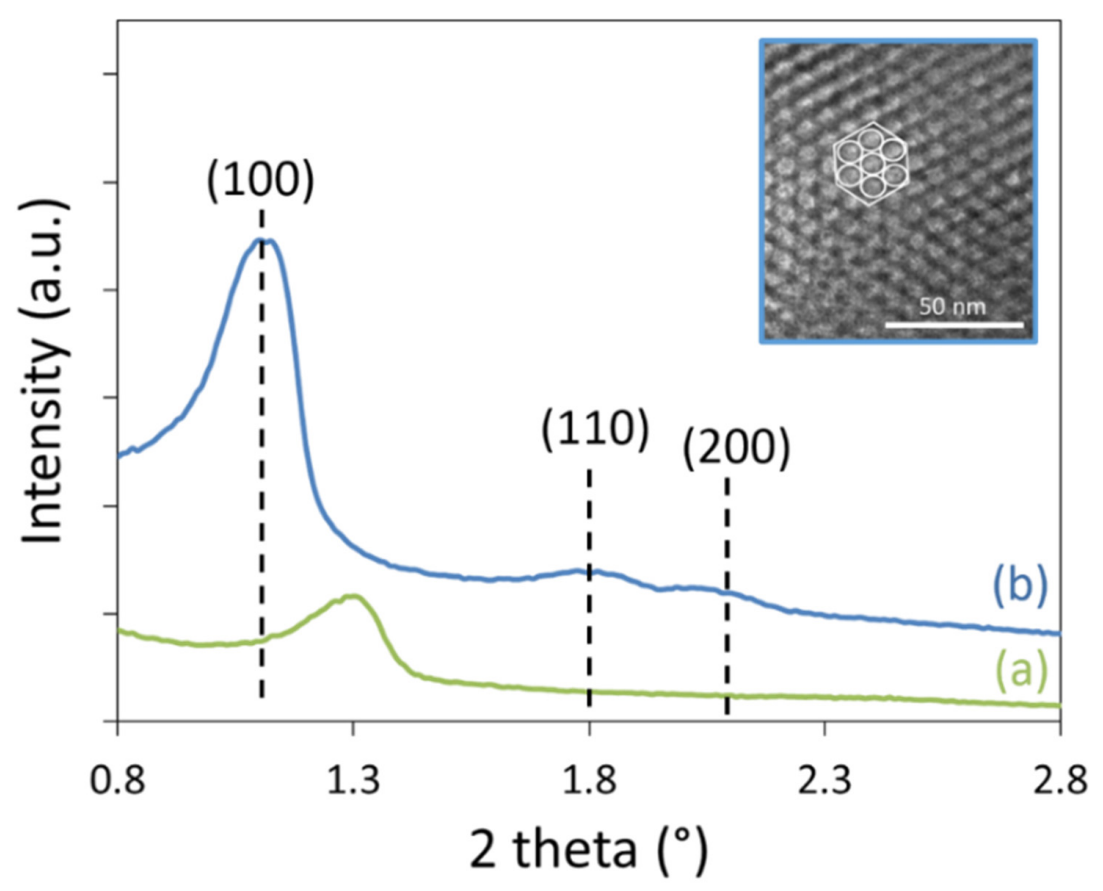

Figure 5. Small-angle XRD patterns of (a) Ni/SBA-15(N), and (b) Ni/SBA- $15_{\mathrm{HT}}(\mathrm{N})$. Inset: TEM image of Ni/SBA-15 $5_{\mathrm{HT}}(\mathrm{N})$ showing the two-dimensional (2D) hexagonal arrangement.

\subsection{Effect of Nickel Precursor and Pre-Treatment}

In order to study the effect of the position of nickel particles, the chloride precursor was employed to promote the deposition of active phase outside the SBA-15 channels [31]. The nitrate and acetate precursors were used to check the effect of the particle size, if any, for a similar position inside the mesoporous structure. It was found that small changes can occur in the textural properties of the SBA- $15_{\mathrm{HT}}$-supported catalysts depending on the nickel precursor salt employed; however, the nature of precursor had the greatest effect on nickel particle size. Indeed, the TEM images of Ni/SBA- $15_{\mathrm{HT}}(\mathrm{N})$ and $\mathrm{Ni} / \mathrm{SBA}-15_{\mathrm{HT}}(\mathrm{Cl})$ samples before (reduced samples) and after (spent samples) reaction show different dispersions of $\mathrm{Ni}^{0}$ metallic particles. The use of nickel nitrate precursor resulted in a narrow distribution of $\mathrm{Ni}^{0}$ particles (Figure 6a), due to the good dispersion of these particles inside the pores of the SBA-15 $5_{\mathrm{HT}}$ support. This dispersion was preserved after the test, as observed from the maintained narrow distribution (Figure 6a'), in addition to few carbon nanotubes observed 
only outside the pores. In opposition, when nickel chloride was used as precursor, a wide particle size distribution up to $100 \mathrm{~nm}$ was obtained (Figure $6 \mathrm{~b}$ ). The large $\mathrm{Ni}^{0}$ nanoparticles formed on $\mathrm{Ni} / \mathrm{SBA}-15_{\mathrm{HT}}(\mathrm{Cl})$ were majorly formed on the external surface of the support (Figures $3 c$ and $6 b$ ), similar to what is typically published regarding the use of the nickel chloride precursor $[17,18,32]$. The higher particle size obtained in $\mathrm{Ni} / \mathrm{SBA}-15_{\mathrm{HT}}(\mathrm{Cl})$ is attributable to the high volatility of nickel chloride used as a precursor in the presence of hydrogen and hydrogen chloride, during calcination and reduction [17,31]. After the test, the number of large particles further increased (Figure $6 b^{\prime}$ ). The absence of carbon formation on this sample is due to its low catalytic activity, as also depicted by the low $\mathrm{H}_{2}$ and $\mathrm{CO}$ yields, which did not exceed $40 \%$ (Table 3 ). The fast and continuous deactivation in this case can be mostly explained by (i) lower initial number of active sites accessible to the reactants, (ii) lack of well-confined nickel nanoparticles inside the channels of the support, and subsequently, (iii) increased mobility of metallic phase resulting in (iv) continuously less accessible metal active sites.
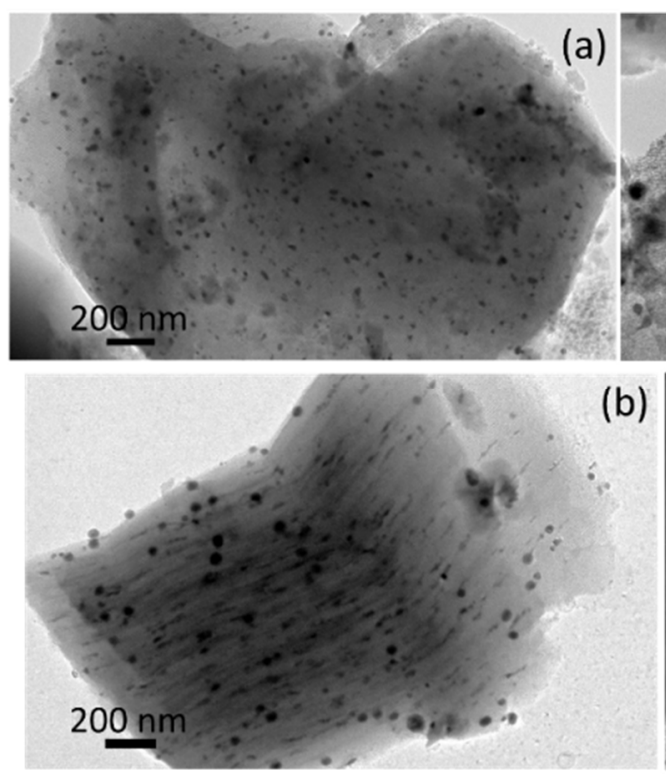

(a)

(b)
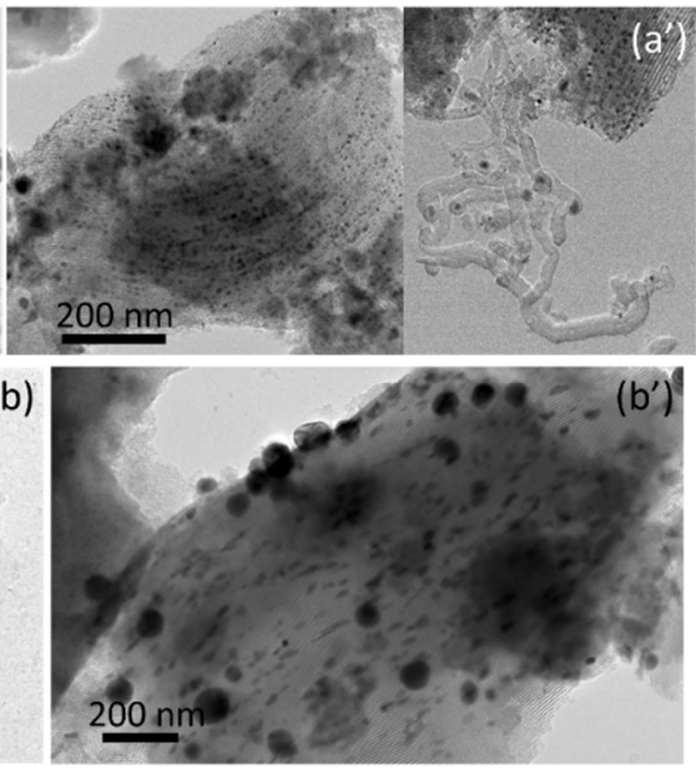

Figure 6. TEM images of (a) reduced $\mathrm{Ni} / \mathrm{SBA}-15_{\mathrm{HT}}(\mathrm{N}),\left(\mathbf{a}^{\prime}\right)$ spent $\mathrm{Ni} / \mathrm{SBA}-15_{\mathrm{HT}}(\mathrm{N})$, (b) reduced $\mathrm{Ni} / \mathrm{SBA}-15_{\mathrm{HT}}(\mathrm{Cl})$, and $\left(\mathbf{b}^{\prime}\right)$ spent $\mathrm{Ni} / \mathrm{SBA}-15_{\mathrm{HT}}(\mathrm{Cl})$.

It was reported that during the calcination treatment in air, the nickel nitrate precursor decomposes and produces oxygen radicals $\left(\mathrm{NO}_{2} / \mathrm{O}_{2}\right)$, which can result in nickel oxide sintering [19]. Alternatively, nickel acetate can be used in order to achieve slightly better nickel dispersion [33]. Another option also resides in the direct reduction of uncalcined sample in $\mathrm{H}_{2}$ atmosphere, eliminating the possible formation of oxygen radicals, even when using the nickel nitrate precursor. Subsequently, the preparation of Ni/SBA- $15_{\mathrm{HT}}(\mathrm{R})$ by skipping the calcination step prior to the reduction helped in generating smaller nickel particles (Table 1). Comparable outcomes were also reported by direct reduction on $\mathrm{Ni} / \mathrm{Al}_{2} \mathrm{O}_{3}$ catalysts for DRM [34] and Ni/SBA-15 catalysts for the hydrogenation of naphthalene [20].

The better catalytic activity, stability, and product yields obtained on $\mathrm{Ni} / \mathrm{SBA}-15_{\mathrm{HT}}(\mathrm{N})$, $\mathrm{Ni} / \mathrm{SBA}-15_{\mathrm{HT}}(\mathrm{A})$, and $\mathrm{Ni} / \mathrm{SBA}-15_{\mathrm{HT}}(\mathrm{R})$ is due to the better dispersion of the small nickel nanoparticles and their better confinement inside the pores. While these catalysts showed comparable $\mathrm{CH}_{4}$ and $\mathrm{CO}_{2}$ conversions (75-85\%), the Ni/SBA- $15_{\mathrm{HT}}(\mathrm{N})$ was more selective, with high yields and $\mathrm{H}_{2}: \mathrm{CO}$ molar ratio closer to unity. The external nickel particles were apparently subjected to a greater carbon deposition and higher degree of sintering, both leading to lower catalytic activity and rapid deactivation. Thus, it is evident that Ni particles deposited inside the porosity of the SBA-15 silica support are more protected and more stable than the ones localized on the external surface of the support for methane dry 
reforming. Ma et al. published comparable results for nickel particles loaded inside carbon nanotubes [13]. Furthermore, the calcination treatment does not appear to be mandatory to achieve good Ni dispersion, high activity, and great stability.

\subsection{Carbon Analysis}

When nickel nanoparticles are well-confined inside the mesopores, the space limitation of the pores hinders any growth of carbon nanotubes around the metallic particle and thus maintains its accessibility and activity. However, when the particles are outside the pores, no restrictions are present and carbon easily diffuse on their surface [35]. In fact, the metal-support interaction influences the type of carbon species formed on the particles [36,37]. Indeed, when the Ni metallic particle is away from the support (absence of interaction), it can be easily encapsulated with carbon, blocking the reaction and causing deactivation [38], since the number of accessible active sites decreases [39]. When the metal-support interaction is weak, carbon nanotubes can form and lift the metallic particle, but without causing its complete deactivation since the particle remains accessible on top of the nanotube $[40,41]$. Nevertheless, this type of carbon might result in pore plugging or even reactor plugging, and sometimes catalyst cracking.

During the methane dry reforming, the equilibrium of the main reaction is simultaneously accompanied by the reverse water-gas shift (RWGS) reaction $\left(\mathrm{CO}_{2}+\mathrm{H}_{2} \rightarrow \mathrm{H}_{2} \mathrm{O}\right.$ $+\mathrm{CO})$. At $650{ }^{\circ} \mathrm{C}, \mathrm{CH}_{4}$ decomposition $\left(\mathrm{CH}_{4} \rightarrow \mathrm{C}_{(\mathrm{s})}+2 \mathrm{H}_{2}\right)$ and/or Boudouard reaction $\left(2 \mathrm{CO} \rightarrow \mathrm{C}_{(\mathrm{s})}+\mathrm{CO}_{2}\right)$ can result in carbon deposition on the surface of the catalyst [42]. The deposited carbon can be either gasified by the water formed during RWGS $\left(\mathrm{C}_{(\mathrm{s})}+\mathrm{H}_{2} \mathrm{O} \rightarrow\right.$ $\mathrm{CO} / \mathrm{CO}_{2}+\mathrm{H}_{2}$ ) or accumulated on the catalyst, leading to activity loss [43].

Consequently, the difference between the rates of carbon formation and gasification affects the rate of catalyst deactivation [44]. Thus, carbon accumulation and catalyst deactivation can only happen when the rate of carbon gasification is lower than that of its formation [41].

In this study, we have demonstrated that the occlusion of nickel nanoparticles inside well-defined porosity is a key parameter for excellent catalytic stability. The confinement of nanoparticles inside the porous channels of the SBA-15 mesoporous supports hinders active-phase sintering and also prevents carbon formation on the internal particles. On the contrary, carbon can easily deposit on external nanoparticles located outside the porous system, as observed on the poorly structured Ni/SBA-15(N), due to the weak metalsupport interaction.

For the spent catalysts, diffraction peaks (Figure $7 a$ ) observed at 44,52 , and $76^{\circ}$ for all samples are assigned to metallic $\mathrm{Ni}^{0}$ (JCPDS 65-0380) with a face-centered cubic lattice (Fm-3m), confirming the maintenance of the reduced metallic nickel active phase in the reforming reaction. As in the case of calcined and reduced samples, both spent $\mathrm{Ni} / \mathrm{SiO}_{2}(\mathrm{~N})$ and spent $\mathrm{Ni} / \mathrm{SBA}-15_{\mathrm{HT}}(\mathrm{Cl})$ show the largest nickel particle size among the catalysts (Table 1).
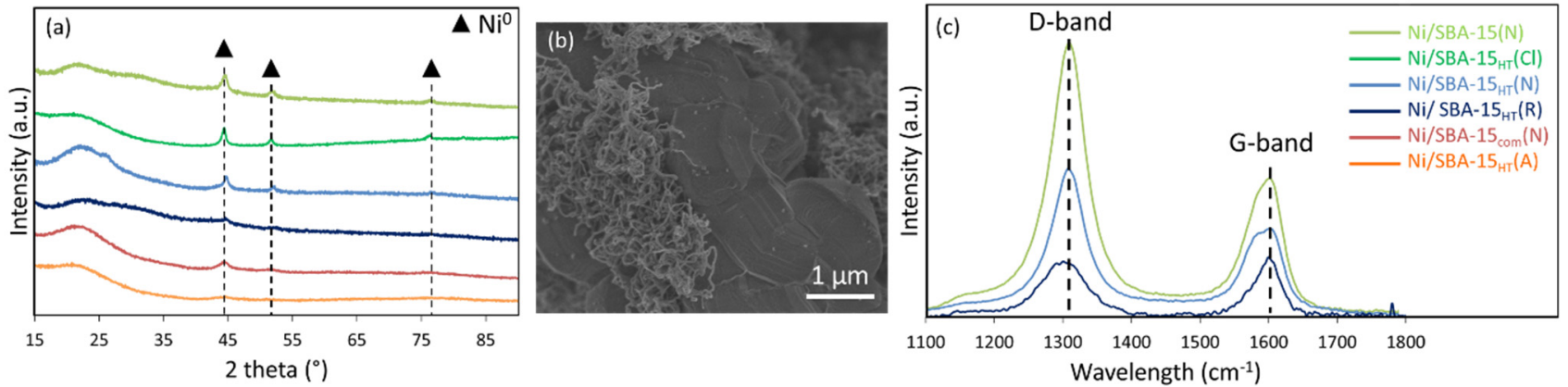

Figure 7. (a) X-ray diffractograms of the spent catalysts, (b) SEM image of the spent Ni/SBA-15(N), and (c) Raman spectra of some spent catalysts. 
On the SEM images of the spent Ni/SBA-15(N) (Figure 7b), a large quantity of carbon nanotubes is observed. Carbon deposition is also seen on the spent $\mathrm{Ni} / \mathrm{SBA}-15_{\mathrm{HT}}(\mathrm{N})$, however this sample still maintained good active-phase dispersion, as seen on the XRD patterns.

The Raman spectrometry technique was used to further study the nature of the carbon deposition. The results (Figure 7c) consist of two main peaks: the G-band near $1600 \mathrm{~cm}^{-1}$ corresponding to in-plane displacement of carbon atoms in hexagonal sheets and the Dband at around $1310 \mathrm{~cm}^{-1}$ attributable to disordered graphite and defects like pentagons and heptagons. The intensity of the D-band relative to that of the G-band, expressed by the $\mathrm{I}_{\mathrm{D}} / \mathrm{I}_{\mathrm{G}}$ ratio, is often used as a measure of the quality of nanotubes. High $\mathrm{I}_{\mathrm{D}} / \mathrm{I}_{\mathrm{G}}$ ratio (Table 1) was obtained on the Ni/SBA-15(N) sample, indicating that most of the carbon on this material was amorphous. Low $\mathrm{I}_{\mathrm{D}} / \mathrm{I}_{\mathrm{G}}$ ratio was obtained for the Ni/SBA$15_{\mathrm{HT}}(\mathrm{R})$ catalyst since very low carbon deposition is seen on the TEM images. Such low carbon amount was also observed on $\mathrm{Ni} / \mathrm{Al}_{2} \mathrm{O}_{3}$ catalyst, subjected to reduction without calcinations [34].

In order to study carbon deposition with time under reactants stream, the catalytic performance of Ni/SBA- $15_{\mathrm{HT}}(\mathrm{N})$ was studied during each test at $650{ }^{\circ} \mathrm{C}$ and $36 \mathrm{~L} \cdot \mathrm{g}^{-1} \cdot \mathrm{h}^{-1}$ while varying the duration time of the stability test. First, the samples were reduced, then, the activity was assessed from 200 up to $750{ }^{\circ} \mathrm{C}$, followed by stability measurements at $650^{\circ} \mathrm{C}$, and the experiment was stopped after $5,20,60$, and $90 \mathrm{~h}$ at this fixed temperature.

The quantification of the carbon formed on these spent catalysts after reaction was done by TGA-MS (Figure 8a). It can be seen that around 5\% weight loss occurred in all cases. This indicates that carbon accumulation was only significant at the beginning but tended to stabilize with time. Comparable results were obtained during DRM reaction on a Ni/MgO-AN catalyst at $750{ }^{\circ} \mathrm{C}$ under 15 bars, but with much more important carbon deposition within $10 \mathrm{~h}$ [45]. The gasification of carbon into $\mathrm{CO}_{2}$ is confirmed by the peak corresponding to the MS signal of mass 44 (Figure $8 \mathrm{~b}$ ), between 500 and $730{ }^{\circ} \mathrm{C}$ for all the samples. This is attributed to the elimination of carbon nanotubes by oxidation, as reported by Braga et al. [46], in agreement with the formation of carbon nanotubes observed by TEM. Furthermore, the Raman measurements indicate that the extent of crystallinity of the formed carbon nanotubes was also constant since the ratio $\mathrm{I}_{\mathrm{D}} / \mathrm{I}_{\mathrm{G}}$ remained at 1.6-1.7 with very limited particles sintering. Consequently, the Ni/SBA- $15_{\mathrm{HT}}(\mathrm{N})$ catalyst was very selective towards the desired reaction with limited manifestation of the side reactions.
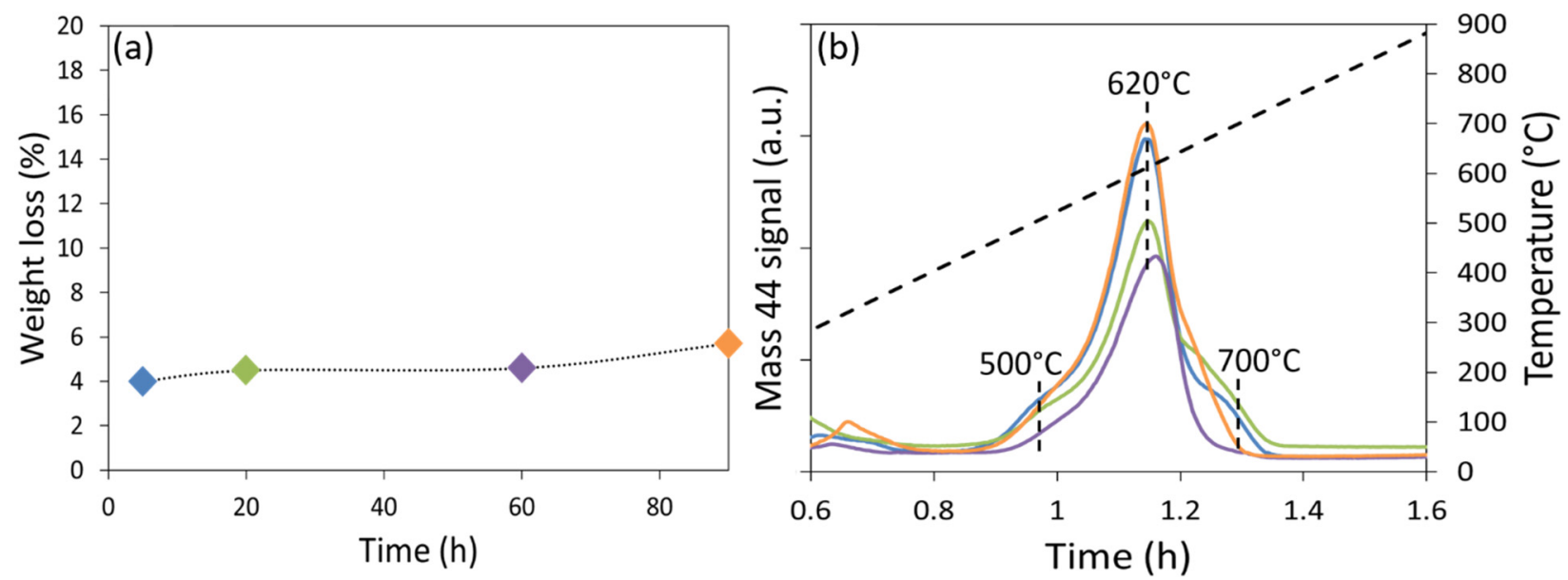

Figure 8. (a) Percentage weight loss during TGA and (b) MS signal for mass 44 of Ni/SBA- $15_{\mathrm{HT}}(\mathrm{N})$ after different stability time durations. 


\section{Materials and Methods}

\subsection{Catalyst Preparation}

The SBA-15 silica support was prepared using a larger scale of the successfully established sol-gel method [12,47]. In detail, after dissolution of $115 \mathrm{~g}$ of P123 (Sigma Aldrich, 435465 ) in $3620 \mathrm{~mL} \mathrm{HCl}$ (1.9 M prepared by dilution in water of a $37 \% \mathrm{HCl}$ solution, Analar Normapur VWR 20252.324) at $120 \mathrm{rpm}$ and $35^{\circ} \mathrm{C}$ for $24 \mathrm{~h}, 364.5 \mathrm{~mL}$ Tetraethyl Orthosilicate, TEOS (Sigma Aldrich, 86578) was added with the aid of a peristaltic pump at a rate of $15 \mathrm{~mL} \cdot \mathrm{min}^{-1}$, and the resulting solution was kept at the same temperature for another $24 \mathrm{~h}$. Part of the synthesis was next subjected to hydrothermal treatment at $95^{\circ} \mathrm{C}$ for $48 \mathrm{~h}$ before filtration, while the remaining part was directly filtered. Calcination was done in air at $500{ }^{\circ} \mathrm{C}$ for $9 \mathrm{~h}$ at $2{ }^{\circ} \mathrm{C} \cdot \mathrm{min}^{-1}$, as reported elsewhere [27], producing SBA- $15_{\mathrm{HT}}$ and SBA-15 supports, with and without hydrothermal treatment, respectively.

For impregnation, all samples were prepared using the "two solvents" technique $[20,48,49]$ that promotes the deposition of metal precursors inside the pores. Briefly, the support was stirred in n-hexane (Sigma Aldrich 37000) for $15 \mathrm{~min}$, and then a specific volume of precursor salt solutions, corresponding to the porous volume of support, was added dropwise. In all samples, the nickel content was $5 \mathrm{wt} \%$.

On the SBA-15 ${ }_{\mathrm{HT}}$ support, nickel nitrate (Sigma Aldrich, 72253), nickel acetate (Sigma Aldrich, 72225), and nickel chloride (Sigma Aldrich, 31462) were used as nickel precursors to obtain $\mathrm{Ni} / \mathrm{SBA}-15_{\mathrm{HT}}(\mathrm{N}), \mathrm{Ni} / \mathrm{SBA}-15_{\mathrm{HT}}(\mathrm{A})$, and Ni/SBA-15 $5_{\mathrm{HT}}(\mathrm{Cl})$, respectively. Nickel nitrate was also deposited on two supports used for comparison, a commercial mesostructured SBA-15 (Sigma Aldrich, 777242) and a fumed silica $\mathrm{SiO}_{2}$ (Sigma Aldrich, 381276), leading to the $\mathrm{Ni} / \mathrm{SBA}-15_{\mathrm{com}}(\mathrm{N})$ and $\mathrm{Ni} / \mathrm{SiO}_{2}(\mathrm{~N})$ samples, respectively.

The dried samples were calcined in air at $450{ }^{\circ} \mathrm{C}$ for $5 \mathrm{~h}$ and designated as shown in Table 1 . The Ni/SBA- $15_{\mathrm{HT}}(\mathrm{R})$ was directly reduced at $650{ }^{\circ} \mathrm{C}$ for $2 \mathrm{~h}$ under $5 \mathrm{vol} \% \mathrm{H}_{2} / \mathrm{Ar}$ $\left(30 \mathrm{~mL} \cdot \mathrm{min}^{-1}\right)$ without calcination.

\subsection{Catalyst Characterization}

Textural properties were determined from $\mathrm{N}_{2}$ sorption isotherms recorded on an ASAP 2020 apparatus (Micromeritics, USA). Before analysis, samples were degassed under vacuum for $2 \mathrm{~h}$ at $250^{\circ} \mathrm{C}$. XRD experiments for small angles were collected between 0.5 and $5^{\circ}$ on a Brüker D8 diffractometer, Germany (Bragg-Brentano, $\mathrm{CuK} \alpha=1.5418 \AA$ ) using a step size of $0.01^{\circ}$ at $1 \mathrm{~s}$ per step and operating at $30 \mathrm{kV}$ and $10 \mathrm{~mA}$. Wide angles were registered on a Panalytical $\mathrm{XPert}^{3}$ diffractometer (Netherlands) using $\mathrm{Cu} \mathrm{K} \alpha$ radiation $(\lambda=1.5405 \AA)$ operating at $30 \mathrm{kV}$ and $10 \mathrm{~mA}$. Measurements were conducted in the range $15<2 \theta\left(^{\circ}\right)<90$, using a step size of $0.039^{\circ}$ and a time per step of $500 \mathrm{~s}$. The average particle sizes were estimated from the full width at half maximum (FWHM) using Scherrer equation $\mathrm{D}=(0.9 \lambda) /(\beta \cos \theta)$, where $\lambda$ is the wavelength $(1.54 \AA), \Theta$ is the Bragg angle, and $B$ is the line broadening at half the maximum intensity, calculated from the Warren equation $\beta=\sqrt{\beta_{\text {measured }}^{2}-\beta_{\text {reference }}^{2}}$ with $\beta_{\text {reference }}=0.18^{\circ}$ or 0.003 rad. Transmission electron microscopy (TEM) images were recorded on a JEM 2010 microscope (JEOL, Tokyo, Japan) operating at $200 \mathrm{keV}$ (LaB6 gun). Scanning electron microscopy (SEM) micrographs were viewed on a Hitachi SU-70 SEM-FEG (Japan) with 30\% of retro-diffused signal. For the Raman experiments, an optical microscope (Kaiser Optical System, Raman Analyzer RXN1 microprobe equipped with a laser diode at $785 \mathrm{~nm}$, USA) was used to focus the laser beam and the spectra were recorded in the $100-3450 \mathrm{~cm}^{-1}$ range. Each analysis was the result of 30 acquisitions of $10 \mathrm{~s}$; the laser power set at $7 \mathrm{~mW}$ to avoid fluorescence effect. Finally, a SDT Q600 (TA Instruments, USA) was coupled to a Thermostar GDS $301 \mathrm{~T} 3$ mass spectrometer (Pfeiffer) and used for the thermogravimetric differential thermal analysis (TG-DTA) measurements. The samples were heated from room temperature to $900{ }^{\circ} \mathrm{C}$ at a rate of $10^{\circ} \mathrm{C} \cdot \mathrm{min}^{-1}$ under air $\left(50 \mathrm{~mL} \cdot \mathrm{min}^{-1}\right)$. The results are expressed as percentage weight loss between the initial and final spent catalysts as a function of the test duration time at the fixed temperature of $650{ }^{\circ} \mathrm{C}$. 


\subsection{Catalytic Testing}

Dry reforming tests were performed at atmospheric pressure in a continuous Hastelloy$X$ fixed-bed reactor (Microactivity, PID Eng and Tech, Spain). First, $100 \mathrm{mg}$ of catalyst was reduced in situ at $650{ }^{\circ} \mathrm{C}$ for $2 \mathrm{~h}\left(10^{\circ} \mathrm{C} \cdot \mathrm{min}^{-1}\right)$ under $5 \mathrm{vol} \% \mathrm{H}_{2} / \mathrm{Ar}$ at $20 \mathrm{~mL} \cdot \mathrm{min}^{-1}$, to ensure complete reduction of $\mathrm{NiO}$ into metallic nickel [24]. Then, the reactants were introduced with a gas hourly space velocity of $36 \mathrm{~L} \cdot \mathrm{g}^{-1} \cdot \mathrm{h}^{-1}\left(\mathrm{CH}_{4}: \mathrm{CO}_{2}: \mathrm{Ar}=5: 5: 90\right)$, and the temperature was increased from 200 to $750{ }^{\circ} \mathrm{C}$ at $5{ }^{\circ} \mathrm{C} \cdot \mathrm{min}^{-1}$. A micro-GC Inficon 3000 apparatus was used to regularly analyze the reactants and products. The equipment has a thermal conductivity detector (TCD) and two columns in parallel for the detection of $\mathrm{CH}_{4}, \mathrm{H}_{2}, \mathrm{CO}$ (Molecular Sieve column), and $\mathrm{CO}_{2}$ (plot-U column). Finally, for stability measurements, the reactor was cooled down to $650{ }^{\circ} \mathrm{C}$ and maintained at this temperature for a certain time. The product selectivities and yields were calculated using the following equations:

$$
\begin{gathered}
S_{\mathrm{H}_{2}}=\frac{\left[\mathrm{H}_{2}\right]}{2 \times\left[\mathrm{CH}_{4}\right]_{\text {converted }}} \times 100 \\
S_{\mathrm{CO}}=\frac{[\mathrm{CO}]}{\left[\mathrm{CH}_{4}\right]_{\text {converted }}+\left[\mathrm{CO}_{2}\right]_{\text {converted }}} \times 100 \\
Y_{\mathrm{H}_{2}}=\frac{\left[\mathrm{H}_{2}\right]}{2 \times\left[\mathrm{CH}_{4}\right]_{\text {in }}} \times 100 \\
Y_{\mathrm{CO}}=\frac{[\mathrm{CO}]}{\left[\mathrm{CH}_{4}\right]_{\text {in }}+\left[\mathrm{CO}_{2}\right]_{\text {in }}} \times 100
\end{gathered}
$$

\section{Conclusions}

In this study, various nickel precursors and supports were used to prepare different catalysts with external and/or internal Ni particles, and their activity and stability in the dry reforming of methane at $650{ }^{\circ} \mathrm{C}$ were evaluated.

Improved catalytic activity can be favored by using a well-defined mesoporous structure, characterized by great surface area and small pore size distribution. This structure allows good confinement of nickel nanoparticles inside the pores, resulting in a superior resistance towards sintering and carbon deposition.

It was shown that the catalytic behavior depended on the nature of the nickel precursor, the active-phase location (inside or outside the pores), and the porosity of the support. Briefly, the nickel precursor (nitrate, acetate, or chloride) did not majorly affect the textural properties of the catalysts but influenced the size and location of the active phase. With nickel chloride, large and external particles were detected on the outer surface of the support, and these were subjected to a great carbon deposition and high degree of sintering, leading to lower catalytic activity and rapid deactivation. The better catalytic activity and stability obtained on both $\mathrm{Ni} / \mathrm{SBA}-15_{\mathrm{HT}}(\mathrm{N})$ and $\mathrm{Ni} / \mathrm{SBA}-15_{\mathrm{HT}}(\mathrm{A})$ was due to the better dispersion of the small nickel nanoparticles and their better confinement inside the pores. Moreover, the calcination step can be skipped, and a direct reduction can lead to good dispersion, high activity, and great catalytic stability.

All these synthesis strategies can be employed in order to obtain well-confined nanoparticles, characterized by good catalytic performance as well as good resistance to sintering, carbon deposition, and consequent deactivation.

It was also shown that on $\mathrm{Ni} / \mathrm{SBA}-15_{\mathrm{HT}}(\mathrm{N})$, tested at $650{ }^{\circ} \mathrm{C}$ for different durations, carbon essentially accumulated during the first few hours of the test, most probably on the external particles, in the form of carbon nanotubes, and later, the rate of carbon deposition and gasification tended to equilibrate.

Author Contributions: Conceptualization, N.E.H. and P.M.; methodology, M.-N.K., N.E.H., A.D. and P.M.; validation, M.-N.K.; formal analysis, M.-N.K., N.E.H. and A.D.; investigation, M.-N.K.; resources, N.E.H. and A.D.; data curation, M.-N.K.; writing—original draft preparation, M.-N.K. and N.E.H.; writing-review and editing, M.-N.K., N.E.H., A.D. and P.M.; visualization, M.-N.K., 
N.E.H., and P.M.; supervision, N.E.H., A.D. and P.M.; project administration, N.E.H. and P.M.; funding acquisition, N.E.H. and P.M. All authors have read and agreed to the published version of the manuscript.

Funding: This research was funded by the ERANET EU-FP7 initiative, the national ANR (France) and CNRS-L (Lebanon) agencies through the SOL-CARE (Energy-065) project (JC-ENERGY-2014 first call). Supports by UOB Research Council (BIRG 14/2012), Center for Innovation \& Technology (Innovation Voucher) in Lebanon and CEDRE France-Lebanon Hubert-Curien (PHC) program are also acknowledged.

Institutional Review Board Statement: Not applicable.

Informed Consent Statement: Not applicable.

Acknowledgments: Special thanks to the technical assistance of Sandra Casale for the TEM/SEM experiments, Hala Fallah for the XRD measurements, and Jean-Marc Krafft for the help in Raman Spectroscopy.

Conflicts of Interest: The authors declare no conflict of interest.

\section{References}

1. Li, D.; Nakagawa, Y.; Tomishige, K. Methane reforming to synthesis gas over Ni catalysts modified with noble metals. Appl. Catal. A Gen. 2011, 408, 1-24. [CrossRef]

2. Pakhare, D.; Spivey, J. A review of dry $\left(\mathrm{CO}_{2}\right)$ reforming of methane over noble metal catalysts. Chem. Soc. Rev. 2014, 43, 7813-7837. [CrossRef] [PubMed]

3. Usman, M.; Wan Daud, W.M.A.; Abbas, H.F. Dry reforming of methane: Influence of process parameters-A review. Renew. Sustain. Energy Rev. 2015, 45, 710-744. [CrossRef]

4. Rostrup-Nielsen, J.R.; Bak Hansen, J.-H. CO -Reforming of Methane over Transition Metals. J. Catal. 1993, 144, 38-49. [CrossRef]

5. Abdullah, B.; Abd Ghani, N.A.; Vo, D.V.N. Recent advances in dry reforming of methane over Ni-based catalysts. J. Clean. Prod. 2017, 162, 170-185. [CrossRef]

6. Li, L.; Chen, J.; Zhang, Q.; Yang, Z.; Sun, Y.; Zou, G. Methane dry reforming over activated carbon supported Ni-catalysts prepared by solid phase synthesis. J. Clean. Prod. 2020, 274, 122256. [CrossRef]

7. Muraleedharan Nair, M.; Kaliaguine, S. Structured catalysts for dry reforming of methane. New J. Chem. 2016, 40, 4049-4060. [CrossRef]

8. Osazuwa, O.U.; Cheng, C.K. Catalytic conversion of methane and carbon dioxide (greenhouse gases) into syngas over samariumcobalt-trioxides perovskite catalyst. J. Clean. Prod. 2017, 148, 202-211. [CrossRef]

9. Sun, N.; Wen, X.; Wang, F.; Wei, W.; Sun, Y. Effect of pore structure on Ni catalyst for $\mathrm{CO}_{2}$ reforming of $\mathrm{CH}_{4}$. Energy Environ. Sci. 2010, 3, 366-369. [CrossRef]

10. El Hassan, N.; Davidson, A.; Da Costa, P.; Djéga-Mariadassou, G. Methane activation by $\mathrm{NO}_{2}$ on Co loaded SBA-15 catalysts: The effect of mesopores (length, diameter) on the catalytic activity. Catal. Today 2008, 137, 191-196. [CrossRef]

11. El Hassan, N.; Kaydouh, M.N.; Geagea, H.; El Zein, H.; Jabbour, K.; Casale, S.; El Zakhem, H.; Massiani, P. Low temperature dry reforming of methane on rhodium and cobalt based catalysts: Active phase stabilization by confinement in mesoporous SBA-15. Appl. Catal. A Gen. 2016, 520, 114-121. [CrossRef]

12. Kaydouh, M.N.; El Hassan, N.; Davidson, A.; Casale, S.; El Zakhem, H.; Massiani, P. Highly active and stable Ni/SBA-15 catalysts prepared by a "two solvents" method for dry reforming of methane. Microporous Mesoporous Mater. 2016, 220, 99-109. [CrossRef]

13. Ma, Q.; Wang, D.; Wu, M.; Zhao, T.; Yoneyama, Y.; Tsubaki, N. Effect of catalytic site position: Nickel nanocatalyst selectively loaded inside or outside carbon nanotubes for methane dry reforming. Fuel 2013, 108, 430-438. [CrossRef]

14. Malek Abbaslou, R.M.; Tavassoli, A.; Soltan, J.; Dalai, A.K. Iron catalysts supported on carbon nanotubes for Fischer-Tropsch synthesis: Effect of catalytic site position. Appl. Catal. A Gen. 2009, 367, 47-52. [CrossRef]

15. Chen, W.; Fan, Z.; Pan, X.; Bao, X. Effect of Confinement in Carbon Nanotubes on the Activity of Fischer-Tropsch Iron Catalyst. J. Am. Chem. Soc. 2008, 130, 9414-9419. [CrossRef]

16. Rao Surisetty, V.; Epelde, E.; Trepanier, M.; Kozinski, J.; Dalai, A.K. The Role of Catalytic Site Deposition on Cobalt Catalysts Supported on Carbon Nanotubes for Fisher-Trospch Synthesis. Int. J. Chem. React. Eng. 2012, 10. [CrossRef]

17. Cornu, A.; Luc Bonardet, J.; Casale, S.; Davidson, A.; Abramson, S.; Andre, G.; Porcher, F.; Grcic, I.; Tomasic, V.; Vujevic, D.; et al. Identification and Location of Iron Species in Fe/SBA-15 Catalysts: Interest for Catalytic Fenton Reactions. J. Phys. Chem. C 2012, 116, 3437-3448. [CrossRef]

18. Manuel García-Vargas, J.; Luís Valverde, J.; de Lucas-Consuegra, A.; Gómez-Monedero, B.; Sánchez, P.; Dorado, F. Precursor influence and catalytic behaviour of $\mathrm{Ni} / \mathrm{CeO}_{2}$ and $\mathrm{Ni} / \mathrm{SiC}$ catalysts for the tri-reforming process. Appl. Catal. A Gen. 2012, 431-432, 49-56. [CrossRef]

19. Hoang-Van, A.; Kachaya, Y.; Teichner, S.J. Characterization of nickel catalysts by chemisorption techniques, X-ray diffraction and magnetic measurements: Effects of support, precursor and hydrogen pretreatment. Appl. Catal. 1989, 46, 281-296. [CrossRef] 
20. Shi-Biao, R.; Zhou, S.; Ping, Z.; Zhi-Cai, W.; Zhi-Ping, L.; Chun-Xiu, P.; Shi-Gang, K.; Heng-Fu, S. Highly dispersed Ni/SBA-15 catalysts prepared with different nickel salts as nickel precursors: Effects of activation atmospheres. J. Fuel Chem. Technol. 2014, 42, 591-596.

21. Marceau, E.; Che, M.; Cejka, J.; Zukal, A. Nickel(II) Nitrate vs. Acetate: Influence of the Precursor on the Structure and Reducibility of Ni/MCM-41 and Ni/Al-MCM-41 Catalysts. ChemCatChem 2010, 2, 413-422. [CrossRef]

22. Thommes, M.; Kaneko, K.; Neimark, A.V.; Olivier, J.P.; Rodriguez-Reinoso, F.; Rouquerol, J.; Sing, K.S.W. Physisorption of gases, with special reference to the evaluation of surface area and pore size distribution (IUPAC Technical Report). Pure Appl. Chem. 2015, 87, 1051-1069. [CrossRef]

23. Ogura, M.; Guillet-Nicolat, R.; Brouri, D.; Casale, S.; Blanchard, J.; Cychosz, K.; Thommes, M.; Thomas, C. Insights into the accessibility of $\mathrm{Zr}$ in Zr/SBA-15 mesoporous silica supports with increasing Zr loadings. Microporous Mesoporous Mater. 2016, 225, 440-449. [CrossRef]

24. Karam, L.; Casale, S.; El Zakhem, H.; El Hassan, N. Tuning the properties of nickel nanoparticles inside SBA-15 mesopores for enhanced stability in methane reforming. J. CO2 Util. 2017, 17, 119-124. [CrossRef]

25. Sokolov, S.; Kondratenko, E.V.; Pohl, M.M.; Barkschat, A.; Rodemerck, U. Stable low-temperature dry reforming of methane over mesoporous $\mathrm{La}_{2} \mathrm{O}_{3}-\mathrm{ZrO}_{2}$ supported Ni catalyst. Appl. Catal. B Environ. 2012, 113-114, 19-30. [CrossRef]

26. $\mathrm{Xu}$, L.; Song, $\mathrm{H}$; Chou, L. Ordered mesoporous $\mathrm{MgO}-\mathrm{Al}_{2} \mathrm{O}_{3}$ composite oxides supported Ni based catalysts for $\mathrm{CO}_{2}$ reforming of CH4: Effects of basic modifier and mesopore structure. Int. J. Hydrog. Energy 2013, 38, 7307-7325. [CrossRef]

27. Zhao, D.; Feng, J.; Huo, Q.; Melosh, N.; Fredrickson, G.H.; Chmelka, B.F.; Stucky, G.D. Triblock Copolymer Syntheses of Mesoporous Silica with Periodic 50 to 300 Angstrom Pores. Science 1998, 279, 548-552. [CrossRef]

28. Galarneau, A.; Cambon, H.; Di Renzo, F.; Fajula, F. True Microporosity and Surface Area of Mesoporous SBA-15 Silicas as a Function of Synthesis Temperature. Langmuir 2001, 17, 8328-8335. [CrossRef]

29. Galarneau, A.; Cambon, H.; Di Renzo, F.; Ryoo, R.; Choi, M.; Fajula, F. Microporosity and connections between pores in SBA-15 mesostructured silicas as a function of the temperature of synthesis. New J. Chem. 2003, 27, 73-79. [CrossRef]

30. Imperor-Clerc, M.; Davidson, P.; Davidson, A. Existence of a Microporous Corona around the Mesopores of Silica-Based SBA-15 Materials Templated by Triblock Copolymers. J. Am. Chem. Soc. 2000, 122, 11925-11933. [CrossRef]

31. Tabaja, N.; Casale, S.; Brouri, D.; Davidson, A.; Obeid, H.; Toufaily, J.; Hamieh, T. Quantum-dots containing Fe/SBA-15 silica as "green" catalysts for the selective photocatalytic oxidation of alcohol (methanol, under visible light). Comptes Rendus Chim. 2015, 18, 358-367. [CrossRef]

32. Wu, G.; Zhang, C.; Li, S.; Han, Z.; Wang, T.; Ma, X.; Gong, J. Hydrogen Production via Glycerol Steam Reforming over $\mathrm{Ni}_{2} \mathrm{Al}_{2} \mathrm{O}_{3}$ : Influence of Nickel Precursors. ACS Sustain. Chem. Eng. 2013, 1, 1052-1062. [CrossRef]

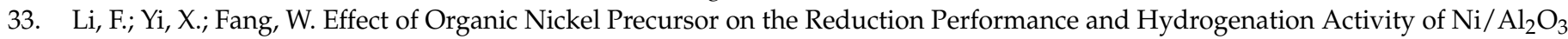
Catalysts. Catal. Lett. 2009, 130, 335-340. [CrossRef]

34. Juan-Juan, J.; Roman-Martinez, M.C.; Illan-Gomez, M.J. Nickel catalyst activation in the carbon dioxide reforming of methane: Effect of pretreatments. Appl. Catal. A Gen. 2009, 355, 27-32. [CrossRef]

35. Huang, T.; Huang, W.; Huang, J.; Ji, P. Methane reforming reaction with carbon dioxide over SBA-15 supported Ni-Mo bimetallic catalysts. Fuel Process. Technol. 2011, 92, 1868-1875. [CrossRef]

36. Wang, N.; Xu, Z.; Deng, J.; Shen, K.; Yu, X.; Qian, W.; Chu, W.; Wei, F. One-pot Synthesis of Ordered Mesoporous NiCeAl Oxide Catalysts and a Study of Their Performance in Methane Dry Reforming. ChemCatChem 2014, 6, 1470-1480. [CrossRef]

37. Yu, M.; Zhu, Y.; Lu, Y.; Tong, G.; Zhu, K.; Zhou, X. The promoting role of Ag in Ni-CeO 2 catalyzed $\mathrm{CH}_{4}-\mathrm{CO}_{2}$ dry reforming reaction. Appl. Catal. B Environ. 2015, 165, 43-56. [CrossRef]

38. Fan, M.S.; Zuhairi Abdullah, A.; Bhatia, S. Catalytic Technology for Carbon Dioxide Reforming of Methane to Synthesis Gas. ChemCatChem 2009, 1, 192-208. [CrossRef]

39. Megía, P.J.; Vizcaíno, A.J.; Ruiz-Abad, M.; Calles, J.A.; Carrero, A. Coke evolution in simulated bio-oil aqueous fraction steam reforming using Co/SBA-15. Catal. Today 2020, in press. [CrossRef]

40. de Llobet, S.; Pinilla, J.L.; Moliner, R.; Suelves, I. Relationship between carbon morphology and catalyst deactivation in the catalytic decomposition of biogas using Ni, Co and Fe based catalysts. Fuel 2015, 139, 71-78. [CrossRef]

41. Serrano-Lotina, A.; Daza, L. Long-term stability test of Ni-based catalyst in carbon dioxide reforming of methane. Appl. Catal. A Gen. 2014, 474, 107-113. [CrossRef]

42. Wang, C.; Sun, N.; Zhao, N.; Wei, W.; Sun, Y.; Sun, C.; Liu, H.; Snape, C.E. Coking and deactivation of a mesoporous Ni-CaO-ZrO 2 catalyst in dry reforming of methane: A study under different feeding compositions. Fuel 2015, 143, 527-535. [CrossRef]

43. Kyu Han, Y.; Ahn, C.; Bae, J.; Kim, R.; Young Han, G. Effects of carbon formation on catalytic performance for $\mathrm{CO}_{2}$ reforming with methane on $\mathrm{Ni} / \mathrm{Al}_{2} \mathrm{O}_{3}$ catalyst: Comparison of fixed-bed with fluidized-bed reactors. Ind. Eng. Chem. Resour. 2013, 52, 13288-13296. [CrossRef]

44. Argyle, M.D.; Bartholomew, C.H. Heterogeneous catalyst deactivation and regeneration: A review. Catalysts 2015, 5, 145-269. [CrossRef]

45. Wang, Y.H.; Wang, H.; Li, Y.; Zhu, Q.M.; Xu, B.Q. Performance of Ni/MgO-AN catalyst in high pressure $\mathrm{CO}_{2}$ reforming of methane. Top. Catal. 2005, 32, 109-116. [CrossRef] 
46. Braga, T.P.; Santos, R.C.R.; Sales, B.M.C.; da Silva, B.R.; Pinheiro, A.N.; Leite, E.R.; Valentini, A. $\mathrm{CO}_{2}$ mitigation by carbon nanotube formation during dry reforming of methane analyzed by factorial design combined with response surface methodology. Chin. J. Catal. 2014, 35, 514-523. [CrossRef]

47. Imperor-Clerc, M.; Bazin, D.; Appay, M.; Beaunier, P.; Davidson, A. Crystallization of $\beta-\mathrm{MnO}_{2}$ Nanowires in the Pores of SBA-15 Silicas: In Situ Investigation Using Synchrotron Radiation. Chem. Mater. 2004, 16, 1813-1821. [CrossRef]

48. Kaydouh, M.N.; El Hassan, N.; Davidson, A.; Casale, S.; El Zakhem, H.; Massiani, P. Effect of the order of Ni and Ce addition in SBA-15 on the activity in dry reforming of methane. Comptes Rendus Chim. 2015, 18, 293-301. [CrossRef]

49. Van der Meer, J.; Bardez-Giboire, I.; Mercier, C.; Revel, B.; Davidson, A.; Denoyel, R.J. Mechanism of Metal Oxide Nanoparticle Loading in SBA-15 by the Double Solvent Technique. J. Phys. Chem. C 2010, 114, 3507-3515. [CrossRef] 